Article

\title{
Simultaneous Removal and Recovery of Metal Ions and Dyes from Wastewater through Montmorillonite Clay Mineral
}

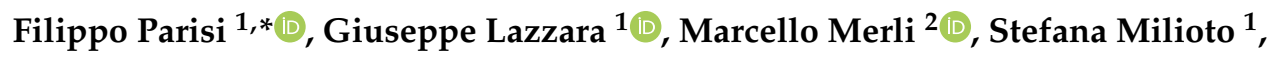 \\ Francesco Princivalle ${ }^{3}$ and Luciana Sciascia ${ }^{2}$ \\ 1 Dipartimento di Fisica e Chimica, Università degli Studi di Palermo, Viale delle Scienze, Ed. 17, \\ 90128 Palermo, Italy; giuseppe.lazzara@unipa.it (G.L.); stefana.milioto@unipa.it (S.M.) \\ 2 Dipartimento di Scienze della Terra e del Mare, Università degli Studi di Palermo, Via Archirafi, 22, \\ 90123 Palermo, Italy; marcello.merli@unipa.it (M.M.); luciana.sciascia@unipa.it (L.S.) \\ 3 Dipartimento di Matematica e Geoscienze, Università degli Studi di Trieste, Via Weiss, 1, 34128 Trieste, Italy; \\ princiva@units.it \\ * Correspondence: filippo.parisi@unipa.it
}

Received: 21 July 2019; Accepted: 27 November 2019; Published: 28 November 2019

\begin{abstract}
The main objective of this work was to evaluate the potential of Montmorillonite nanoclay (Mt), readily and inexpensively available, for the simultaneous adsorption (and removal) of two classes of pollutants: metal ions and dyes. The attention was focused on two "model" pollutants: $\mathrm{Ce}(\mathrm{III})$ and crystal violet $(\mathrm{CV})$. The choice is due to the fact that they are widespread in wastewaters of various origins. These characteristics, together with their effect on human health, make them ideal for studies on water remediation. Moreover, when separated from wastewater, they can be recycled individually in industrial production with no or simple treatment. Clay/pollutant hybrids were prepared under different $\mathrm{pH}$ conditions and characterized through the construction of the adsorption isotherms and powder X-ray diffraction. The adsorption behavior of the two contaminants was revealed to be significantly different: the Langmuir model reproduces the adsorption isotherm of $\mathrm{Ce}(\mathrm{III})$ better, thus indicating that the clay offers a unique adsorption site to the metal ions, while the Freundlich model proved to be the most reliable for the uptake of CV which implies heterogeneity of adsorption sites. Moreover, metal ions do not adsorb at all under acidic conditions, whereas the dye is able to adsorb under all the investigated conditions. The possibility to modulate the adsorption features by simply changing the $\mathrm{pH}$ conditions was successfully employed to develop an efficient protocol for the removal and separation of the different components from aqueous solutions mimicking wastewaters.
\end{abstract}

Keywords: Montmorillonite; adsorption; wastewaters; metal ions; dyes

\section{Introduction}

The disposal of wastewaters from various origins represents a serious environmental issue due to the simultaneous presence of different types of pollutants [1-4]. Dyes and metals are widely used and often jointly released in large quantities from industrial activities such as dye manufacturing, the textile and leather tannery industries, pulp and paper processing, battery production [5-11].

Owing to their toxic potential and their recalcitrant capacity, discharge of metal ions and dyes effluents can cause potential hazards to environment and human health [12-24].

All conventional methods applied for the treatment of dyes and/or heavy metals [25-32] have peculiar limitations related to cost, efficiency and operational difficulties [11,33-36]. Among them, adsorption was revealed as one of the most effective methods due to its simple operation, versatility, 
high-treatment efficiency and low cost, and it is therefore widely applied for the treatment of wastewaters [37-48].

Several kinds of natural or chemically modified materials including activated carbons, carbon nanotubes, zeolites and clays [8,49-58], were investigated to remove contaminants from effluents. In recent years, there has been growing interest in clay minerals which are green, inexpensive and effective adsorption substrates [5,59-65].

Aside from their large surface area, the adsorption properties of clay minerals are mostly related to the negative charges generated by isomorphic substitutions. Generally, these negative charges are neutralized by exchangeable ions thus allowing the adsorption of positively charged cations through cation exchange processes. For these reasons clay minerals display a strong attraction to cationic species, such as dyes and metal ions [55,66-70].

Specifically, montmorillonite (Mt), whose structure consists of $\sim 1 \mathrm{~nm}$ thick alluminosilicate layers, was largely employed in remediation due to its noteworthy properties, including large specific surface area and presence of nano-pores, high cations exchange capacity, presence of several types of active sites on the surface, easy availability, eco-friendliness and non-toxicity [71-78].

In this context is inserted the present work where Mt mineral clay was employed for the treatment of water samples containing two "model" pollutants. The organic dye crystal violet (CV) and the $\mathrm{Ce}(\mathrm{III})$ metal ions were chosen as models for dye metals because they are both in the cationic form in a wide range of $\mathrm{pH}$, they are widespread in wastewaters of various origin, and have a toxic effect on human health, making them ideal for a study on water remediation. Moreover, when separated from wastewater, they can be recycled individually in industrial production [79].

In more detail, crystal violet is largely employed in textile and paper industries, in veterinary pharmacology and in bacteriology as Gram stain [79]. In spite of the great range of applications, crystal violet is a mutagen, carcinogenic and mitotic poison $[80,81]$ and therefore the disposal of effluents is an important environmental issue.

As for the $\mathrm{Ce}(\mathrm{III})$ species, it represents the most abundant element of rare earth metals and has several applications in engineering, agriculture, catalysis, nuclear energy, metallurgy, pharmaceutical, and removal from radioactive wastes [82-88]. Cerium compounds are considered to be moderately toxic [89-92] with their tendency to accumulate in the bones, liver, heart and lung and to react with enzyme and phospholipids [93,94]. Moreover, cerium in forms of nitrate and chloride could induce chromosomal breaks [95] and intensifying the cardiac effects of magnesium deficiency [96], respectively. Due to the toxic effect and the simultaneous technological importance of $\mathrm{Ce}(\mathrm{III})$, separation and recovery of these metal ions from effluents has a significant environmental and economic impact.

The removal of both $\mathrm{Ce}(\mathrm{III})$ and $\mathrm{CV}$ from aqueous solutions through adsorption onto various substrates, including clay minerals, was investigated by various authors $[20,24,34,81,83,97,98]$. However, a systematic study aimed to develop an efficient procedure for their simultaneous removal and separation is still lacking.

In the light of the above considerations, the aim of this work was to exploit the adsorption features of Mt clay for the treatment of aqueous solutions containing crystal violet and Cerium(III) as models for dyes and metals. Although different works concerning multicomponent adsorption were performed $[99,100]$ in order to better clarify the adsorption mechanism and to propose a separation protocol, the adsorption behavior of the two contaminants separately was investigated here. Batch adsorption experiments were performed under different $\mathrm{pH}$ conditions and the adsorption isotherms were constructed in order to elucidate the adsorption mechanism and establish the nature of the interactions. The sites of interactions of the clay surface were proposed on the basis of the XRD results. Then, based on the information obtained, two different procedures were developed to remove simultaneously and separate the metal ions and dyes from the effluent. 


\section{Materials and Methods}

\subsection{Materials}

All the reactants, i.e., K10-Montmorillonite $(\mathrm{Mt})$, hydrochloric acid $(\mathrm{HCl})$, sodium hydroxide $(\mathrm{NaOH})$ standard solutions, $\mathrm{Ce}(\mathrm{III})$ nitrate hexahydrate $(\mathrm{Ce}(\mathrm{III}))$ and crystal violet $\left(\mathrm{CV}, \mathrm{C}_{25} \mathrm{H}_{30} \mathrm{ClN}_{3}\right.$, $\mathrm{Mw}=407.99 \mathrm{~g} \mathrm{~mol}^{-1}$, water solubility $=50 \mathrm{mg} \mathrm{mL}^{-1}$ at $27{ }^{\circ} \mathrm{C}, \mathrm{K}_{\mathrm{ow}}=0.51$ ) were purchased from Sigma Aldrich and used as received. The structural formula of $\mathrm{K} 10-\mathrm{Mt}$ is reported as follows:

$\left(\mathrm{K}_{0.25} \mathrm{Na}_{0.118} \mathrm{Ca}_{0.022}\right)\left(\mathrm{Al}_{1.06} \mathrm{Fe}_{0.206} \mathrm{Mg}_{0.166}\right)\left(\mathrm{Si}_{7.39} \mathrm{Al}_{0.61}\right) \mathrm{O}_{20}(\mathrm{OH})_{4}$.

The BET (Brunauer-Emmett-Teller) surface area is $220 \mathrm{~m}^{2} / \mathrm{g}$, the CEC is $119 \mathrm{meq} / 100 \mathrm{~g}$, the total pore volume is $0.3 \mathrm{~cm}^{3} / \mathrm{g}$ and the average pore size is $6.25 \mathrm{~nm}$. Pore size distribution (PSD) curves reveal that $80 \%$ of pores have a diameter $<25 \mathrm{~nm}$ with a peak at $4.04 \mathrm{~nm}$ [101].

Zeta potential measurements reported in literature for K10-Montmorillonite [78] showed that it does not present isoelectric point, being the clay surface negatively charged at all $\mathrm{pH}$ values.

Deionized water from reverse osmosis (Elga, model Option 3), having a specific resistance higher than $1 \mathrm{M} \Omega \mathrm{cm}$, was used to prepare all solutions.

\subsection{Samples Preparation}

Aqueous $\mathrm{HCl}$ and $\mathrm{NaOH}$ solutions at the desired $\mathrm{pH}$ were prepared by proper dilution of the corresponding standard solution.

Pollutant stock solutions and Mt suspensions were prepared by weighing the proper amounts of the components and dissolving them with the aqueous solutions at the required $\mathrm{pH}$, according to the procedure already reported in the literature [72]. When necessary the $\mathrm{pH}$ of the aqueous solutions/dispersions were adjusted to the desired value by adding microvolumes of either $\mathrm{HCl}$ or $\mathrm{NaOH}$ standard solution. The clay dispersions were stirred for about $2 \mathrm{~h}$ before use.

In order to construct the adsorption isotherms, appropriate aliquots of the metal or dye solutions were added to the $\mathrm{Mt}$ dispersion at room temperature $\left(25^{\circ} \mathrm{C}\right)$. The pollutant concentrations were changed in the range from $(2.0 \pm 0.1) \times 10^{-4}$ to $(4.0 \pm 0.2) \times 10^{-3} \mathrm{~g} \mathrm{dm}^{-3}$, while the amount of Mt was kept constant at $0.40 \pm 0.02 \mathrm{~g} \mathrm{dm}^{-3}$. The mixture was stirred at $100 \mathrm{rpm}$ for $24 \mathrm{~h}$, a stirring time which ensures that the adsorption processes reaches the equilibrium, as demonstrated by preliminary kinetic experiments. At the end of the adsorption process the $\mathrm{pH}$ of the obtained dispersions was checked. No significant changes were observed. The dispersion was then centrifuged $1 \mathrm{~h}$ at 10,000 rpm by means of a Centra MP4R IEC centrifuge (Thermo Fisher Scientific, Waltham, MA, USA). The supernatant was separated from the solid, which was air-dried at room temperature, crushed in an agate mortar and employed for X-ray diffraction (XRD) characterization.

The gathered supernatants were spectrophotometrically analyzed by registering the spectra of the aqueous pollutant solutions in the wavelength range 200-700 $\mathrm{nm}$ with a diode-array S600 spectrophotometer (Analytic Jena, Jena, Thuringia, Germany) equipped with thermostated compartments for $1 \mathrm{~cm} \times 1 \mathrm{~cm} \times 5 \mathrm{~cm}$ cuvettes and an appropriate magnetic stirring apparatus. Triplicate experiments were performed and the results are reported as the average value of each single measurement.

The molar adsorption coefficient values $(\varepsilon)$ of $\mathrm{CV}$ and $\mathrm{Ce}(\mathrm{III})$ at two different $\mathrm{pH}$ conditions were determined by constructing the calibration curves (Table 1)

Table 1. Molar adsorption coefficient values $\left(\varepsilon, \mathrm{M}^{-1} \mathrm{~cm}^{-1}\right)$ of crystal violet (CV) and Ce(III) at $\mathrm{pH} 3.0$ and 7.0.

\begin{tabular}{ccc}
\hline & pH Conditions & $\varepsilon, \mathbf{M}^{-\mathbf{1}} \mathbf{c m}^{-\mathbf{1}}$ \\
\hline $\mathbf{C V}$ & $\mathrm{pH} 3.0$ & $42000 \pm 800$ \\
$\left(\lambda_{\text {max }}=\mathbf{5 9 1} \mathbf{n m}\right)$ & $\mathrm{pH} \mathrm{7.0}$ & $73800 \pm 300$ \\
Ce(III) & $\mathrm{pH} 3.0$ & $740 \pm 30$ \\
$\left(\lambda_{\text {max }}=\mathbf{2 5 3} \mathbf{n m}\right)$ & $\mathrm{pH} \mathrm{7.0}$ & $860 \pm 50$ \\
\hline
\end{tabular}




\subsection{X-ray Diffraction (XRD) Characterization}

Powder X-ray diffractometry measurements were performed for the Mt/contaminant hybrids and for the clay in the absence of additives. Samples were mounted on aluminum plates and the XRD patterns were acquired at room temperature with an STOE D500 (Siemens, Monaco, Germany) with Cu $\mathrm{K} \alpha$ radiation, $\lambda=1.5418 \AA$, generated at $40 \mathrm{kV}$ and $20 \mathrm{~mA}$, in the range of scattering angles $2 \theta=4^{\circ}-25^{\circ}$ at the rate of $0.01^{\circ} / \mathrm{s}$.

\section{Results}

\subsection{Effect of $p H$ Solution on Adsorption Efficiency}

Since clay surface is negatively charged at all $\mathrm{pH}$ values [78], Mt surface is ideal for the uptake of cations.

In order to compare the amount of the two contaminants adsorbed onto the clay under different $\mathrm{pH}$ conditions $(\mathrm{pH}=3.0,5.0,7.0,9.0)$, preliminary experiments were performed by mixing $0.04 \mathrm{~g} \mathrm{dm}^{-3}$ of $\mathrm{CV}$ or $\mathrm{Ce}(\mathrm{III})$ with $0.4 \mathrm{~g} \mathrm{dm}^{-3}$ of Mt. The dispersion obtained was then stirred and centrifuged and the supernatants were analysed spectrophotometrically as already described. The results, expressed in terms of weight percentage, i.e (mass of adsorbed component/initial mass) $\times 100 \%$, are summarized in Table 2.

Table 2. Weight percentage of CV and Ce(III) adsorbed onto Mt mineral clay.

\begin{tabular}{cccc}
\hline & pH 3.0 & pH 5.0 & pH 7.0 \\
\hline CV & $73 w t \%$ & $78 w t \%$ & $95 w t \%$ \\
Ce(III) & 0 & 0 & $50 w t \%$ \\
\hline
\end{tabular}

Results are not reported for the highest value of $\mathrm{pH}(\mathrm{pH}=9.0)$, since it was observed that the stability of the clay suspension is strongly decreased at high $\mathrm{pH}$, thus leading to low reproducibility of the experiments.

Despite the fact that both contaminants are in the cationic form at the investigated $\mathrm{pH}$ range [102-104], a marked difference in the adsorption behavior between the species is clearly evidenced from data in Table 2. In more detail, Ce(III) metal ions do not adsorb onto clay at acidic $\mathrm{pH}$ at all, while the dye is able to adsorb at the three investigated $\mathrm{pH}$ conditions. The higher $\mathrm{pH}$ favors significantly the uptake of the dye according to what is observed for instance in [76] for the adsorption of methyl green dye molecule onto Mt clay.

As widely reported in the literature $[72,105,106]$ the uptake of cationic species onto Mt clay occurs through cationic exchange processes in the clay interlayer and electrostatic interactions with the permanent negative charges on the clay surface. Moreover, the effect of the $\mathrm{pH}$-dependent charges has to be taken into account: the abundance of $\mathrm{H}^{+}$ions at acidic $\mathrm{pH}$, imparts a repulsive force toward the positively charged species, thus hampering their uptake. The results obtained in the present work seem to indicate that electrostatic repulsions are predominant in the case of the adsorption of Ce(III) metal ions and less influent in the case of the crystal violet.

\subsection{Adsorption Isotherms}

The adsorption isotherms, where the equilibrium amount of pollutant adsorbed into the clay $\left(\mathrm{Cs}, \mathrm{g} \mathrm{g}^{-1}\right)$ is plotted as a function of the equilibrium concentration in solution $\left(\mathrm{Ce}, \mathrm{g} \mathrm{dm}^{-3}\right)$, are reported in Figure 1. In the light of the results reported in 3.1, two representative values of $\mathrm{pH}$ (pH 3.0 and $\mathrm{pH}=7.0)$ were taken under consideration. It is worth underlining that, under the applied experimental conditions, no Ce(III) precipitation was observed. 


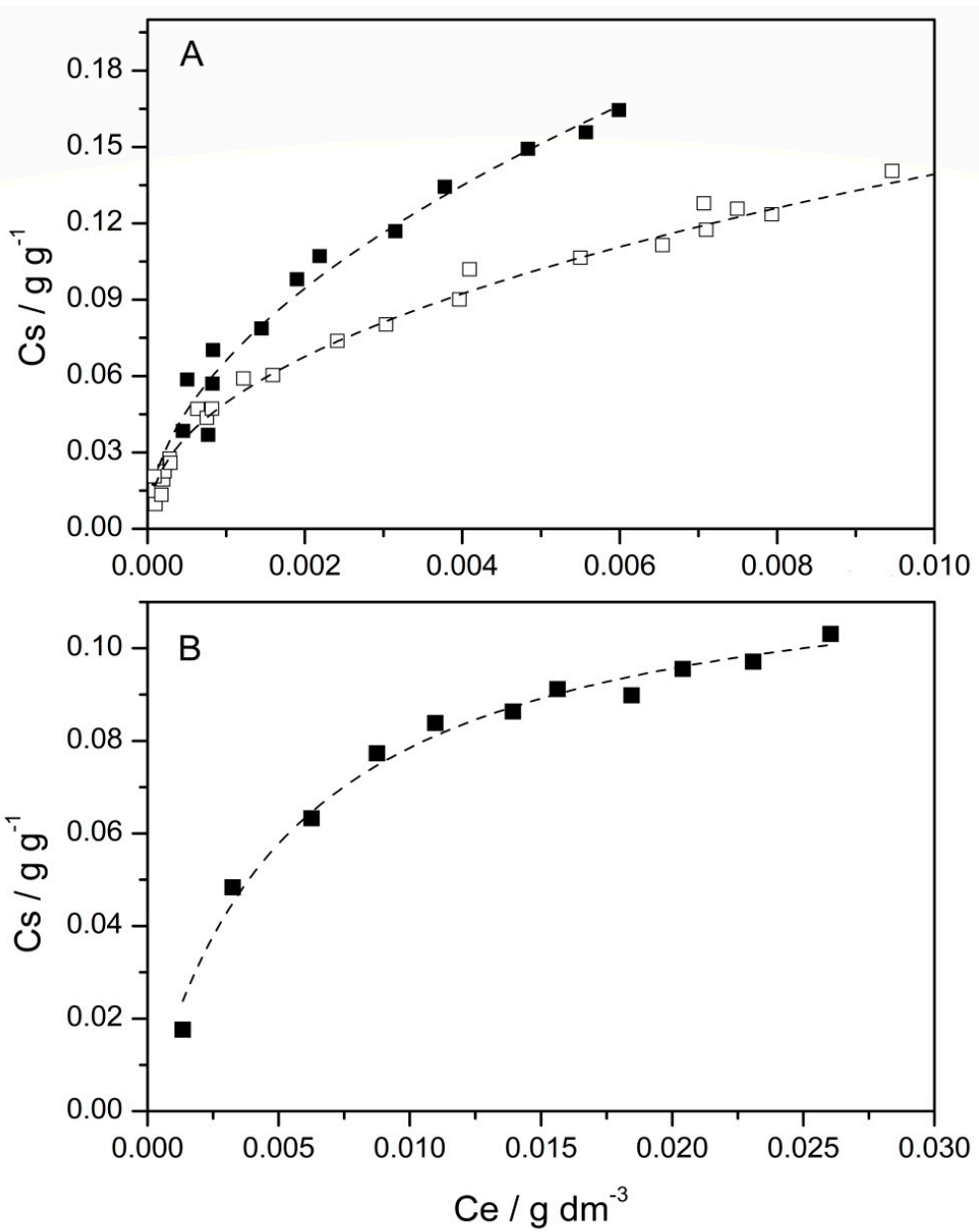

Figure 1. Adsorption isotherm of (A) $\mathrm{CV}$ and (B) $\mathrm{Ce}(\mathrm{III})$ onto $\mathrm{Mt}$ performed at $\mathrm{pH}=7.0$ and $\mathrm{pH}=3.0(\square)$. Lines correspond to the fit by Freundlich and Langmuir models, for CV and $\mathrm{Ce}(\mathrm{III})$ respectively.

As already observed the uptake of the dye is lower under the more acidic conditions, while the metal ions adsorb onto clay only at the higher $\mathrm{pH}$ value.

The following two models were used for fitting the adsorption isotherms:

- Langmuir isotherm:

$$
C_{s}=\frac{q^{m} K_{L} C_{e}}{1+K_{L} C_{e}}
$$

where $q^{m}$ and $K_{L}$ are Langmuir coefficients related to adsorption capacity and adsorption equilibrium constant respectively;

- $\quad$ Freundlich isotherm model:

$$
C_{s}=K_{F} C_{e}^{1 / n}
$$

where $K_{F}$ and $n$ are Freundlich coefficients related to adsorption capacity and adsorption intensity, respectively.

The discrimination between the two models was performed by means of the statistical criteria described in [107] based on advanced statistical diagnostics and robust fitting techniques. The sorption parameters obtained and the most commonly applied statistics are collected in Table 3. 
Table 3. Sorption parameters and selected figures of merit of the two applied models, for the adsorption isotherms of the contaminants onto the Mt.

\begin{tabular}{|c|c|c|c|c|c|c|}
\hline & & \multicolumn{5}{|c|}{$\begin{array}{c}\text { Langmuir } \\
C_{s}=\frac{q^{m} K_{L} C_{e}}{1+K_{L} C_{e}}\end{array}$} \\
\hline & & $q^{m}, g^{-1}$ & $\mathrm{~K}_{\mathrm{L}}, \mathrm{dm}^{3} \mathrm{~g}^{-1}$ & $\mathbf{R}^{2}$ & $x^{2}$ & ESS \\
\hline \multirow[b]{2}{*}{$\mathrm{CV}$} & pH 3.0 & $0.155 \pm 0.007$ & $480 \pm 60$ & 0.969 & $6.0 \times 10^{-5}$ & $1.3 \times 10^{-3}$ \\
\hline & pH 7.0 & $0.22 \pm 0.02$ & $430 \pm 70$ & 0.961 & $8.8 \times 10^{-5}$ & $1.0 \times 10^{-3}$ \\
\hline \multirow[t]{3}{*}{$\mathrm{Ce}(\mathrm{III})$} & pH 7.0 & $0.122 \pm 0.004$ & $180 \pm 20$ & 0.984 & $1.0 \times 10^{-5}$ & $9.2 \times 10^{-5}$ \\
\hline & & \multicolumn{5}{|c|}{$\begin{array}{l}\text { Freundlich } \\
C_{s}=K_{F} C_{e}^{1 / n}\end{array}$} \\
\hline & & $\mathbf{n}$ & $K_{F},\left(g^{-1}\right)\left(d^{3} g^{-1}\right)^{1 / n}$ & $\mathbf{R}^{2}$ & $x^{2}$ & ESS \\
\hline \multirow{2}{*}{$\mathrm{CV}$} & pH 3.0 & $2.2 \pm 0.1$ & $1.1 \pm 0.1$ & 0.985 & $2.9 \times 10^{-5}$ & $6.3 \times 10^{-4}$ \\
\hline & pH 7.0 & $2.0 \pm 0.1$ & $2.3 \pm 0.4$ & 0.967 & $7.4 \times 10^{-5}$ & $8.8 \times 10^{-4}$ \\
\hline $\mathrm{Ce}(\mathrm{III})$ & pH 7.0 & $2.5 \pm 0.3$ & $0.5 \pm 0.1$ & 0.923 & $5.0 \times 10^{-5}$ & $4.5 \times 10^{-4}$ \\
\hline
\end{tabular}

The Freundlich model proved to be the most reliable for the uptake of CV which implies heterogeneity of adsorption sites and/or formation of multilayers [108-111], while the Langmuir model better reproduces the adsorption isotherm of $\mathrm{Ce}(\mathrm{III})$, indicating that the clay offers a unique adsorption site to the metal ions. Adsorption isotherms reported in Figure 1 clearly evidences the higher adsorption capacity of $\mathrm{CV}$ with respect to $\mathrm{Ce}(\mathrm{III})$. However, since the two contaminants adsorb through different mechanisms, the adsorption parameters obtained are not suitable for comparison.

As for the dye uptake, $K_{F}$ coefficient is higher at the higher $\mathrm{pH}$, thus confirming that the excess of $\mathrm{H}^{+}$ions at the acidic $\mathrm{pH}$ hampers the $\mathrm{CV}$ adsorption. The Freundlich constant values $\mathrm{n}>1.0$ indicate the occurrence of favorable adsorption [78] and do not show significant variation with $\mathrm{pH}$ within the error bars. The obtained parameters are in line with those reported literature for the adsorption of $\mathrm{CV}$ onto K10-Montnorillonite [78,112]. Comparison with other adsorbents evidences the higher efficiency of $\mathrm{Mt}[33,113,114]$.

To the best of the authors' knowledge, no data related to the adsorption of Ce(III) cations onto K10-Mt are available. The adsorption capacity values reported in literature for the uptake onto different supports [115-117] are of the same order of magnitude or lower than those obtained in the present work.

Comparable values of adsorption efficiency are achieved with the application of membrane separation processes, i.e., micro-, nano- or ultra-filration or reverse osmosis [118-120] in the removal of both classes of contaminants. However, although quite effective, these methods are characterized by elevated maintenance and operation costs and high energy requirements $[118,121]$ which make them unsuitable, especially for small and medium industries.

Information about the kind of energy that governs the adsorption process was obtained by applying the Dubinin-Radushkevich (DR) equation (Figure 2):

$$
\ln C_{s}=\ln \mathrm{Xm}-\mathrm{k} \varepsilon^{2}
$$

where

$$
\varepsilon=\mathrm{RT} \ln \left(1+1 / C_{e}\right)
$$

is the Polanyi potential, $\mathrm{R}\left(\mathrm{KJ} \mathrm{mol}^{-1} \mathrm{~K}^{-1}\right)$ is the gas constant, $\mathrm{T}(\mathrm{K})$ is temperature, $\mathrm{Xm}\left(\mathrm{g} \mathrm{g}^{-1}\right)$ is the adsorption capacity of the adsorbent, and $\mathrm{k}\left(\mathrm{mol}^{2} \mathrm{KJ}^{-2}\right)$ is the DR isotherm constant related to the adsorption energy through the following equation:

$$
\mathrm{E}=1 / \sqrt{ }(2 \mathrm{k})
$$



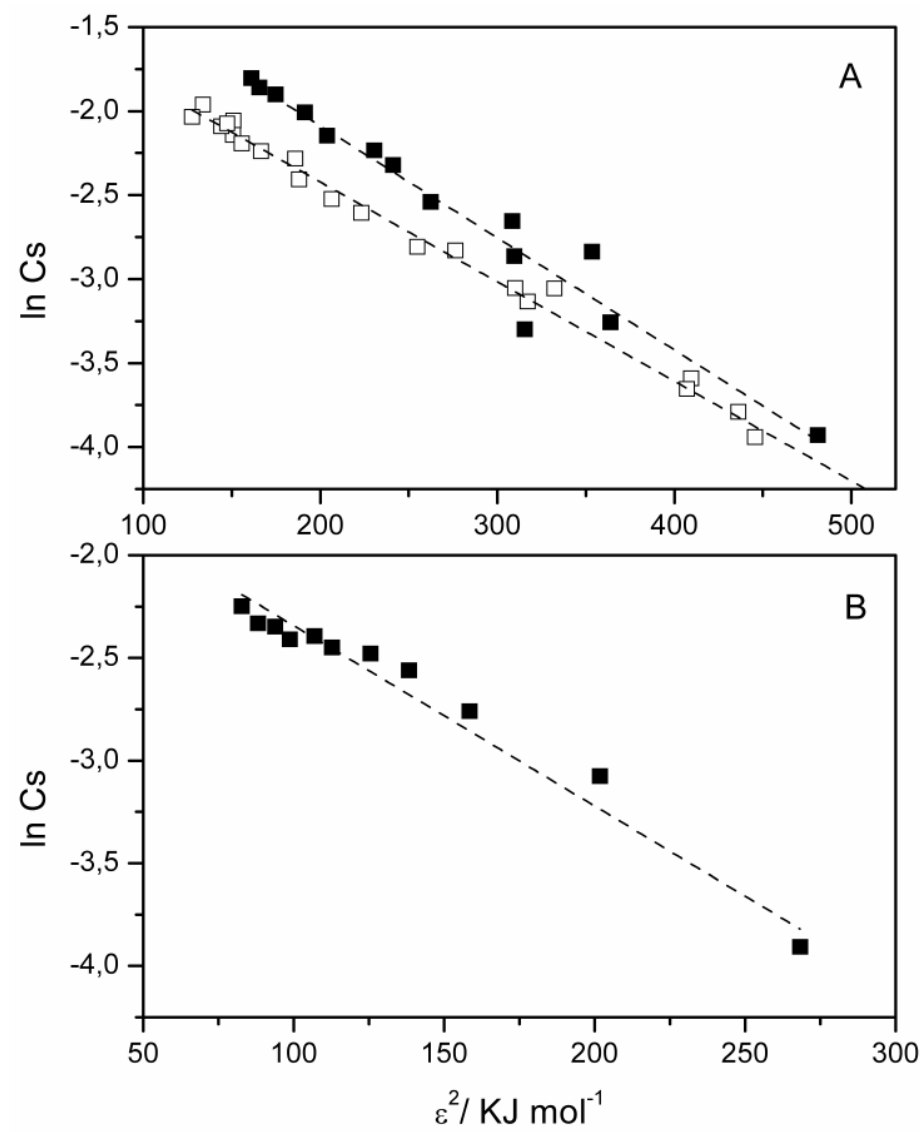

Figure 2. Dubinin-Radushkevich (DR) adsorption isotherms of (A) CV and (B) Ce(III) onto Mt performed at $\mathrm{pH}=7.0(\mathbf{\square})$ and $\mathrm{pH}=3.0(\square)$; line corresponds to the fit by DR equation.

The obtained values of the sorption parameters are reported in Table 4 .

Table 4. Sorption parameters of the Dubinin-Radushkevich model for the adsorption isotherms of the contaminants onto the Mt.

\begin{tabular}{cccccc}
\hline & & $\mathbf{X}^{\mathbf{m}}, \mathbf{g ~ g}^{\mathbf{- 1}}$ & $\mathbf{K}, \mathbf{~ m o l}^{\mathbf{2}} \mathbf{K J}^{-\mathbf{2}}$ & $\mathbf{E}, \mathbf{K J ~ m o l}^{-\mathbf{1}}$ & $\mathbf{R}^{\mathbf{2}}$ \\
\hline & $\mathbf{p H}=\mathbf{3 . 0}$ & $0.47 \pm 0.08$ & $(5.9 \pm 0.2) \times 10^{-4}$ & $9.2 \pm 0.3$ & 0.9599 \\
$\mathbf{C V}$ & $\mathbf{p H}=\mathbf{7 . 0}$ & $0.29 \pm 0.05$ & $(6.7 \pm 0.5) \times 10^{-4}$ & $8.6 \pm 0.6$ & 0.9349 \\
$\mathbf{C e}(\mathrm{III})$ & $\mathbf{p H}=\mathbf{7 . 0}$ & $0.23 \pm 0.01$ & $(8.8 \pm 0.7) \times 10^{-4}$ & $7.5 \pm 0.6$ & 0.9377 \\
\hline
\end{tabular}

As for the dye, the $E$ values obtained were in the range of adsorption energy $\left(8-16 \mathrm{KJ} \mathrm{mol}^{-1}\right)$ characteristic for adsorption systems dominated by chemical ion-exchange mechanism [122-124], while for the metal ions a borderline value was obtained, thus indicating that occurrence of other mechanisms than cation exchange, i.e., direct bonding between metal cations with the surface of clay (electrostatic interactions) and/or surface complexation [125].

The different modes of adsorption and their dependence on the $\mathrm{pH}$ conditions suggest the possibility to properly modulate the removal and recovery of effluent contaminants. Therefore, the employment of Mt nanoclay as sorbent offer a versatile method for the decontamination and valorization of wastewaters containing different types of pollutants.

\subsection{XRD Characterization}

XRD patterns of unmodified and modified Mt samples, registered in the very low angle range, are reported in Figure 3. 


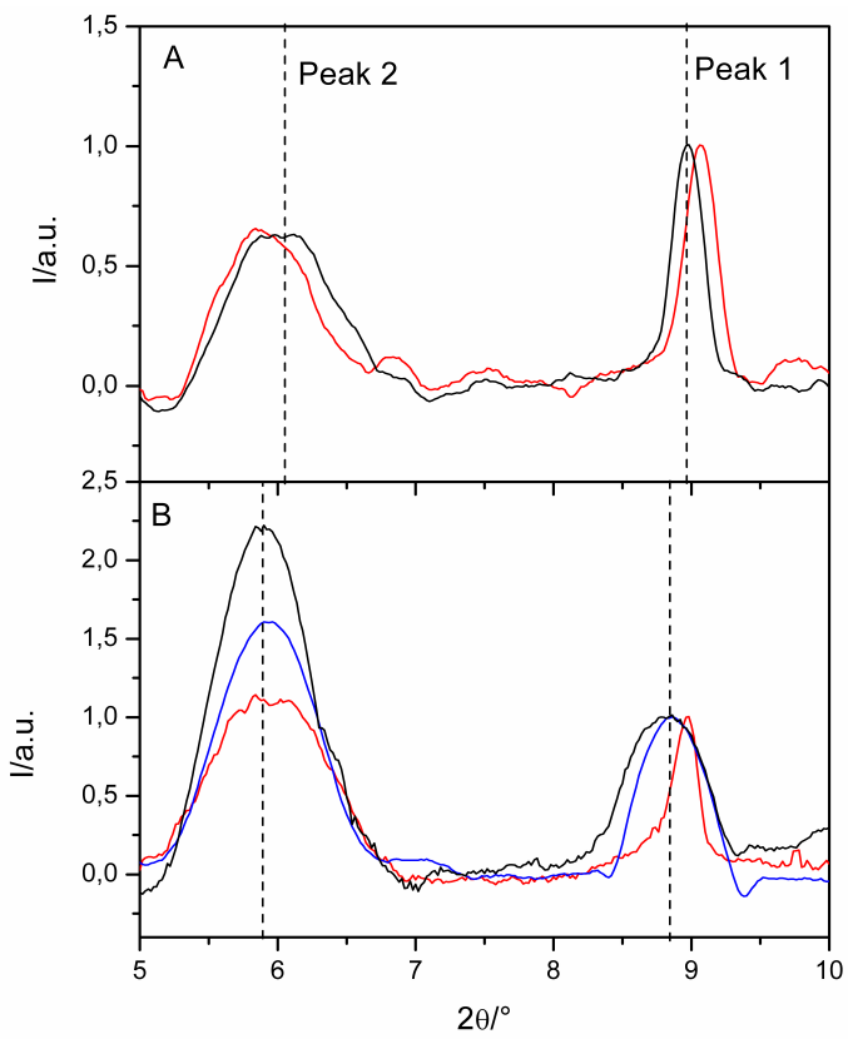

Figure 3. X-ray diffraction (XRD) patterns of pristine Mt (black line), CV/Mt hybrids (red line) and $\mathrm{Ce}(\mathrm{III}) / \mathrm{Mt}$ (blue line) at prepared at $\mathrm{pH}=3.0(\mathbf{A})$ and $\mathrm{pH}=7.0(\mathbf{B})$.

Perusal of diffractograms evidences the presence of the peaks characteristic of the hydrated montmorillonite $\mathrm{k} 10$ clay, i.e., one at $2 \theta$ approximately equal to $8.9^{\circ}$ (peak 1 ) which corresponds to the basal interlayer, and a reflection peak at a lower $2 \theta$ value $\left(\sim 6^{\circ}\right)$ (peak 2), which, according to literature [74,126-130], is attributed to the majority of the interlayer spaces being intercalated with water molecules as proved by the disappearance of this refection peak after dehydration processes [129].

Comparison between the XRD patterns of the unmodified Mt hydrated at the $\mathrm{pH} 3.0$ and 7.0, reveals that acidic conditions lead to a shrinking of the clay interlayer. This can probably be due to exchange processes between $\mathrm{H}^{+}$and the larger cations placed in the clay structure.

Hybrid samples have structural characteristics nearly identical to the unmodified $\mathrm{Mt}$, thus indicating that the clay structure is maintained during the adsorption processes.

As for the positions of the peaks, no changes are detected in the presence of the metal Ce(III), which means that the clay interlayer was not affected by $\mathrm{Ce}$ (III) exchange reactions. This behavior is consistent with the results of the adsorption isotherms previously described and it is in line with the study of [131] that suggested that metal cations were fixed solely on the outer surfaces of the clay.

By contrast, the adsorption of CV leads to a small shift in the peaks positions. In more detail, peak 1 moves towards higher $2 \theta$ values, at both investigated $\mathrm{pH}$ values, thus indicating a contraction of the basal interlayer. The lower interplanar distance after dye adsorption could be taken as an indication of the occurrence of cation exchange processes which displace cations from the interlayer spaces as already observed in (Bromberg et al., 2011; Calabrese et al., 2017; Cui et al., 2008).

A perusal of the position of peak 2 reveals that the entrance of $\mathrm{CV}$ at $\mathrm{pH} 3.0$ leads to an enlargement of the interlayer spaces intercalated with water molecules from $\mathrm{d}=14.5 \AA$ to $\mathrm{d}=15.0 \AA$, while at $\mathrm{pH}$ 7.0 the dimension of the clay interlayer is already $d=15.0 \AA$ and no changes are detected.

It is worth to underline that the different behavior of metal and dye is in accordance with the results of the adsorption isotherms and it corroborates the hypothesis that the dye adsorbs onto $\mathrm{Mt}$ 
clay through both exchange processes and interaction with the outer surface, while metal ions do not enter the clay interlayer.

\subsection{Protocol for the Removal and Separation of Pollutants}

The information obtained about the different behavior of the two pollutants on varying $\mathrm{pH}$ was exploited to develop a procedure for the removal and separation of the two species from a solution mimicking an effluent containing the same amount of the two contaminants $\left(\sim 8 \times 10^{-2} \mathrm{~g} \mathrm{dm}^{-3}\right)$.

The solution was treated, according to the method already developed in the first part of the present work, with a suspension of $\mathrm{Mt}\left(2.0 \mathrm{~g} \mathrm{dm}^{-3}\right)$ at $\mathrm{pH} 3.0$ in order to remove only the CV. The ultraviolet-visible (UV-vis) spectrum of the supernatant obtained from the centrifugation of the obtained dispersion was registered (see Figure 4), then $\mathrm{pH}$ was brought to 7.0 and treated again with $\mathrm{Mt}$, in order to remove the metal ions from the solution.

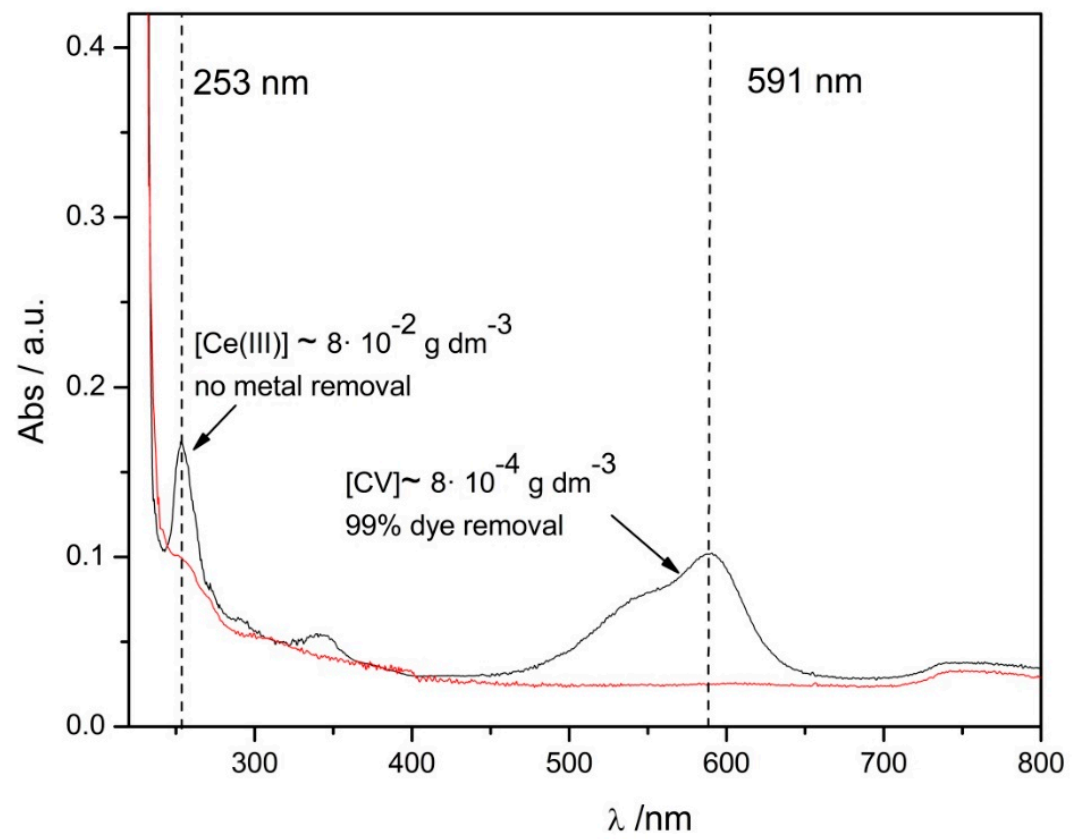

Figure 4. Ultraviolet-visible (UV-vis) spectrum of a mixture containing $\sim 8 \times 10^{-2} \mathrm{~g} \mathrm{dm}^{-3}$ of CV and $\mathrm{Ce}(\mathrm{III})$ after the treatment with $\mathrm{Mt}$ at $\mathrm{pH} 3.0$ (black line) and after the subsequent with $\mathrm{Mt}$ at $\mathrm{pH} 7.0$ (red line).

The spectrum of the pollutant's mixture after the treatment with $\mathrm{Mt}$ at $\mathrm{pH} 3.0$ (black line) reveals the presence of a peak corresponding to $\sim 8 \times 10^{-4} \mathrm{~g} \mathrm{dm}^{-3}$ of $\mathrm{CV}(\lambda=591 \mathrm{~nm})$ indicating the removal of the $99 \%$ of the dye, and a peak corresponding to $\sim 8 \times 10^{-2} \mathrm{~g} \mathrm{dm}^{-3}$ of $\mathrm{Ce}(\mathrm{III})(\lambda=253 \mathrm{~nm})$ indicating that the applied procedure does not remove the metal from the solution at all. The subsequent treatment at pH 7.0 (red line) leads to the total removal of both the contaminants.

In the light of the results obtained it can be concluded that the proposed protocol can be efficiently applied for the separation and removal of the two different kinds of pollutant, if simultaneously present in a wastewater sample. Although, at this stage, experiments on the regeneration of the clay were not still performed, the results obtained open up the possibility to recover and re-use the two contaminants

Experiments were also performed where a solution containing the same amount of $\mathrm{Ce}(\mathrm{III})$ and $\mathrm{CV}$ $\left(8 \times 10^{-2} \mathrm{~g} \mathrm{dm}^{-3}\right)$ at $\mathrm{pH} 7.0$ was treated with $2.0 \mathrm{~g} \mathrm{dm}^{-3}$ of Mt. It was observed that the procedure allows the removal of both contaminants and can be applied efficiently when the separation of the contaminants is not required. 


\section{Conclusions}

The performance of montmorillonite clay in the decontamination of aqueous solutions containing different types of contaminants were verified here. Crystal violet and Cerium (III) were chosen as models for dyes and metals. The adsorption process from effluents containing the two pollutants separately was first investigated at $\mathrm{pH} 3.0$ and $\mathrm{pH}=7.0$, thus revealing significant differences in the behavior of the two species under the different experimental conditions. Adsorption isotherms and XRD measurements were performed in order to characterize the system. Then, based on the information obtained, a procedure was proposed and successfully applied to remove simultaneously and separate the metal ions and dye from wastewaters containing both contaminants.

These results can be helpful for further studies in scale-up processes using real effluents characterized by the presence of different types of pollutants.

Author Contributions: Investigation, F.P. (Filippo Parisi) and L.S.; Writing and Original Draft Preparation, F.P. (Filippo Parisi) and L.S.; Review and Editing, L.S., G.L., M.M. and F.P. (Filippo Parisi); Supervision, L.S., F.P. (Filippo Parisi), G.L. and M.M.; Validation, F.P. (Francesco Princivalle) and M.M; Resources and Funding Acquisition, G.L., F.P (Francesco Princivalle) and S.M.

Funding: This research was funded by the University of Palermo and the University of Trieste.

Conflicts of Interest: The authors declare no conflict of interest.

\section{References}

1. Camera-Roda, G.; Loddo, V.; Palmisano, L.; Parrino, F. Photocatalytic ozonation for a sustainable aquaculture: A long-term test in a seawater aquarium. Appl. Catal. B Environ. 2019, 253, 69-76. [CrossRef]

2. Toledano Garcia, D.; Ozer, L.Y.; Parrino, F.; Ahmed, M.; Brudecki, G.P.; Hasan, S.W.; Palmisano, G. Photocatalytic ozonation under visible light for the remediation of water effluents and its integration with an electro-membrane bioreactor. Chemosphere 2018, 209, 534-541. [CrossRef] [PubMed]

3. Neagu, S.; Cojoc, R.; Enache, M.; Mocioiu, O.C.; Precupas, A.; Popa, V.T.; Gomoiu, I.; Enache, M. Biotransformation of Waste Glycerol from Biodiesel Industry in Carotenoids Compounds by Halophilic Microorganisms. Waste Biomass Valorization 2019, 10, 45-52. [CrossRef]

4. Matei, E.; Covaliu, C.I.; Predescu, A.; Berbecaru, A.; Tarcea, C.; Predescu, C. Remediation of Wastewater with Ultraviolet Irradiation Using a Novel Titanium (IV) Oxide Photocatalyst. Anal. Lett. 2019, 52, 2180-2187. [CrossRef]

5. Cataldo, S.; Cavallaro, G.; Gianguzza, A.; Lazzara, G.; Pettignano, A.; Piazzese, D.; Villaescusa, I. Kinetic and equilibrium study for cadmium and copper removal from aqueous solutions by sorption onto mixed alginate/pectin gel beads. J. Environ. Chem. Eng. 2013, 1, 1252-1260. [CrossRef]

6. Fancello, D.; Scalco, J.; Medas, D.; Rodeghero, E.; Martucci, A.; Meneghini, C.; De Giudici, G. XRD-Thermal Combined Analyses: An Approach to Evaluate the Potential of Phytoremediation, Phytomining, and Biochar Production. Int. J. Environ. Res. Public Health 2019, 16, 1976. [CrossRef] [PubMed]

7. Leulescu, M.; Rotaru, A.; Pălărie, I.; Moanţă, A.; Cioateră, N.; Popescu, M.; Morîntale, E.; Bubulică, M.V.; Florian, G.; Hărăbor, A.; et al. Tartrazine: Physical, thermal and biophysical properties of the most widely employed synthetic yellow food-colouring azo dye. J. Therm. Anal. Calorim. 2018, 134, 209-231. [CrossRef]

8. Politi, D.; Sidiras, D. Wastewater Treatment for Dyes and Heavy Metals Using Modified Pine Sawdust as Adsorbent. Procedia Eng. 2012, 42, 1969-1982. [CrossRef]

9. Rotaru, A.; Dumitru, M. Thermal behaviour of CODA azoic dye liquid crystal and nanostructuring by drop cast and spin coating techniques. J. Therm. Anal. Calorim. 2017, 127, 21-32. [CrossRef]

10. Varrica, D.; Dongarrà, G.; Alaimo, M.G.; Monna, F.; Losno, R.; Sanna, E.; De Giudici, G.; Tamburo, E. Lead isotopic fingerprint in human scalp hair: The case study of Iglesias mining district (Sardinia, Italy). Sci. Total Environ. 2018, 613-614, 456-461. [CrossRef]

11. Visa, M.; Bogatu, C.; Duta, A. Simultaneous adsorption of dyes and heavy metals from multicomponent solutions using fly ash. Appl. Surf. Sci. 2010, 256, 5486-5491. [CrossRef]

12. Cheng, Y.; Feng, Q.; Ren, X.; Yin, M.; Zhou, Y.; Xue, Z. Adsorption and removal of sulfonic dyes from aqueous solution onto a coordination polymeric xerogel with amino groups. Colloids Surf. Physicochem. Eng. Asp. 2015, 485, 125-135. [CrossRef] 
13. Crini, G. Non-conventional low-cost adsorbents for dye removal: A review. Bioresour. Technol. 2006, 97, 1061-1085. [CrossRef] [PubMed]

14. Giridhar, P.; Venugopalan, A.; Parimalan, R. A Review on Annatto Dye Extraction, Analysis and Processing-A Food Technology Perspective. J. Sci. Res. Rep. 2014, 3, 327-348. [CrossRef]

15. Iqbal, M.; Nisar, J. Cytotoxicity and mutagenicity evaluation of gamma radiation and hydrogen peroxide treated textile effluents using bioassays. J. Environ. Chem. Eng. 2015, 3, 1912-1917. [CrossRef]

16. Jain, R.; Sikarwar, S. Photocatalytic and Adsorption Studies on the Removal of Dye Congo Red from Wastewater. Int. J. Environ. Pollut. 2006, 27, 158-178. [CrossRef]

17. Khan, N.; Kazi, T.G.; Tuzen, M.; Soylak, M. A multivariate study of solid phase extraction of beryllium(II) using human hair as adsorbent prior to its spectrophotometric detection. Desalin. Water Treat. 2015, 55, 1088-1095. [CrossRef]

18. Kim, J.S.; Lee, C.H.; Han, S.H.; Suh, M.Y. Studies on complexation and solvent extraction of lanthanides in the presence of diaza-18-crown-6-di-isopropionic acid. Talanta 1997, 45, 437-444. [CrossRef]

19. Parrino, F.; García-López, E.; Marcì, G.; Palmisano, L.; Felice, V.; Sora, I.N.; Armelao, L. Cu-substituted lanthanum ferrite perovskites: Preparation, characterization and photocatalytic activity in gas-solid regime under simulated solar light irradiation. J. Alloys Compd. 2016, 682, 686-694. [CrossRef]

20. Seyahmazegi, E.N.; Mohammad-Rezaei, R.; Razmi, H. Multiwall carbon nanotubes decorated on calcined eggshell waste as a novel nano-sorbent: Application for anionic dye Congo red removal. Chem. Eng. Res. Des. 2016, 109, 824-834. [CrossRef]

21. Shuai, A.; Xueyan, L.; Lijun, Y.; Lei, Z. Enhancement removal of crystal violet dye using magnetic calcium ferrite nanoparticle: Study in single- and binary-solute. Chem. Eng. Res. Des. 2015, 94, 726-735.

22. Trudić, B.; Kebert, M.; Popovic, B.; Stajner, D.; Orlović, S.; Galović, V.; Pilipovic, A. The Effect of Heavy Metal Pollution in Soil on Serbian Poplar Clones. Sumar. List 2013, 137, 287-296.

23. Wang, Y.; Xie, Y.; Zhang, Y.; Tang, S.; Guo, C.; Wu, J.; Lau, R. Anionic and cationic dyes adsorption on porous poly-melamine-formaldehyde polymer. Chem. Eng. Res. Des. 2016, 114, 258-267. [CrossRef]

24. Xiong, C.; Liu, X.; Yao, C. Effect of pH on sorption for RE(III) and sorption behaviors of Sm(III) by D152 resin. J. Rare Earths 2008, 26, 851-856. [CrossRef]

25. Bhatti, I.A.; Ahmad, N.; Iqbal, N.; Zahid, M.; Iqbal, M. Chromium adsorption using waste tire and conditions optimization by response surface methodology. J. Environ. Chem. Eng. 2017, 5, 2740-2751. [CrossRef]

26. Bibi, I.; Nazar, N.; Iqbal, M.; Kamal, S.; Nawaz, H.; Nouren, S.; Safa, Y.; Jilani, K.; Sultan, M.; Ata, S.; et al. Green and eco-friendly synthesis of cobalt-oxide nanoparticle: Characterization and photo-catalytic activity. Adv. Powder Technol. 2017, 28, 2035-2043. [CrossRef]

27. Bilal, M.; Iqbal, M.; Hu, H.; Zhang, X. Mutagenicity and cytotoxicity assessment of biodegraded textile effluent by Ca-alginate encapsulated manganese peroxidase. Biochem. Eng. J. 2016, 109, 153-161. [CrossRef]

28. Hussain, F.; Shah, S.Z.; Zhou, W.; Iqbal, M. Microalgae screening under $\mathrm{CO}_{2}$ stress: Growth and micro-nutrients removal efficiency. J. Photochem. Photobiol. B 2017, 170, 91-98. [CrossRef]

29. Idrissi, M.; Miyah, Y.; Benjelloun, Y.; Chaouch, M. Degradation of crystal violet by heterogeneous Fenton-like reaction using Fe/Clay catalyst with $\mathrm{H}_{2} \mathrm{O}_{2}$. J. Mater. Environ. Sci. 2016, 7, 50-58.

30. Kausar, A.; Bhatti, H.N.; Iqbal, M.; Ashraf, A. Batch versus column modes for the adsorption of radioactive metal onto rice husk waste: Conditions optimization through response surface methodology. Water Sci. Technol. 2017, 76, 1035-1043. [CrossRef]

31. Shoukat, S.; Bhatti, H.N.; Iqbal, M.; Noreen, S. Mango stone biocomposite preparation and application for crystal violet adsorption: A mechanistic study. Microporous Mesoporous Mater. 2017, 239, 180-189. [CrossRef]

32. Turabik, M. Adsorption of basic dyes from single and binary component systems onto bentonite: Simultaneous analysis of Basic Red 46 and Basic Yellow 28 by first order derivative spectrophotometric analysis method. J. Hazard. Mater. 2008, 158, 52-64. [CrossRef] [PubMed]

33. Anirudhan, T.S.; Ramachandran, M. Adsorptive removal of basic dyes from aqueous solutions by surfactant modified bentonite clay (organoclay): Kinetic and competitive adsorption isotherm. Process Saf. Environ. Prot. 2015, 95, 215-225. [CrossRef]

34. Kausar, A.; Iqbal, M.; Javed, A.; Aftab, K.; Nazli, Z.-H.; Bhatti, H.N.; Nouren, S. Dyes adsorption using clay and modified clay: A review. J. Mol. Liq. 2018, 256, 395-407. [CrossRef]

35. Toor, M.; Jin, B.; Dai, S.; Vimonses, V. Activating natural bentonite as a cost-effective adsorbent for removal of Congo-red in wastewater. J. Ind. Eng. Chem. 2015, 21, 653-661. [CrossRef] 
36. Wu, D.; Niu, C.; Li, D.; Bai, Y. Solvent extraction of scandium(III), yttrium(III), lanthanum(III) and gadolinium(III) using Cyanex 302 in heptane from hydrochloric acid solutions. J. Alloy. Compd. 2004, 374, 442-446. [CrossRef]

37. Allen, S.J.; Mckay, G.; Porter, J.F. Adsorption isotherm models for basic dye adsorption by peat in single and binary component systems. J. Colloid Interface Sci. 2004, 280, 322-333. [CrossRef]

38. Gupta, V.K.; Mittal, A.; Krishnan, L.; Gajbe, V. Adsorption kinetics and column operations for the removal and recovery of malachite green from wastewater using bottom ash. Sep. Purif. Technol. 2004, 40, 87-96. [CrossRef]

39. Kamińska, G.; Dudziak, M.; Kudlek, E.; Bohdziewicz, J. Preparation, Characterization and Adsorption Potential of Grainy Halloysite-CNT Composites for Anthracene Removal from Aqueous Solution. Nanomaterials 2019, 9, 890. [CrossRef]

40. Mittal, A.; Kurup (Krishnan), L.; Gupta, V.K. Use of waste materials-Bottom Ash and De-Oiled Soya, as potential adsorbents for the removal of Amaranth from aqueous solutions. J. Hazard. Mater. 2005, 117, 171-178. [CrossRef]

41. Molino, A.; Erto, A.; Natale, F.D.; Donatelli, A.; Iovane, P.; Musmarra, D. Gasification of Granulated Scrap Tires for the Production of Syngas and a Low-Cost Adsorbent for Cd(II) Removal from Wastewaters. Ind. Eng. Chem. Res. 2013, 52, 12154-12160. [CrossRef]

42. Sadraei, R.; Paganini, C.M.; Calza, P.; Magnacca, G. An Easy Synthesis for Preparing Bio-Based Hybrid Adsorbent Useful for Fast Adsorption of Polar Pollutants. Nanomaterials 2019, 9, 731. [CrossRef] [PubMed]

43. Sert, Ş.; Kütahyali, C.; İnan, S.; Talip, Z.; Çetinkaya, B.; Eral, M. Biosorption of lanthanum and cerium from aqueous solutions by Platanus orientalis leaf powder. Hydrometallurgy 2008, 90, 13-18. [CrossRef]

44. Vijayaraghavan, K.; Balasubramanian, R. Single and binary biosorption of cerium and europium onto crab shell particles. Chem. Eng. J. 2010, 163, 337-343. [CrossRef]

45. Walker, G.M.; Hansen, L.; Hanna, J.-A.; Allen, S.J. Kinetics of a reactive dye adsorption onto dolomitic sorbents. Water Res. 2003, 37, 2081-2089. [CrossRef]

46. Wang, J.; Zhuang, S. Removal of various pollutants from water and wastewater by modified chitosan adsorbents. Crit. Rev. Environ. Sci. Technol. 2017, 47, 2331-2386. [CrossRef]

47. XU, S.; Zhang, S.; Chen, K.; Han, J.; Liu, H.; Wu, K. Biosorption of $\mathrm{La}^{3+}$ and $\mathrm{Ce}^{3+}$ by Agrobacterium sp. HN1. J. Rare Earths 2011, 29, 265-270. [CrossRef]

48. Yagub, M.T.; Sen, T.K.; Afroze, S.; Ang, H.M. Dye and its removal from aqueous solution by adsorption: A review. Adv. Colloid Interface Sci. 2014, 209, 172-184. [CrossRef]

49. Almasri, D.A.; Saleh, N.B.; Atieh, M.A.; McKay, G.; Ahzi, S. Adsorption of phosphate on iron oxide doped halloysite nanotubes. Sci. Rep. 2019, 9, 3232. [CrossRef]

50. Asere, T.G.; Stevens, C.V.; Laing, G.D. Use of (modified) natural adsorbents for arsenic remediation: A review. Sci. Total Environ. 2019, 676, 706-720. [CrossRef]

51. Celis, R.; HermosÍn, M.C.; Cornejo, J. Heavy Metal Adsorption by Functionalized Clays. Environ. Sci. Technol. 2000, 34, 4593-4599. [CrossRef]

52. Erdem, E.; Karapinar, N.; Donat, R. The removal of heavy metal cations by natural zeolites. J. Colloid Interface Sci. 2004, 280, 309-314. [CrossRef] [PubMed]

53. Khare, S.K.; Panday, K.K.; Srivastava, R.M.; Singh, V.N. Removal of victoria blue from aqueous solution by fly ash. J. Chem. Technol. Biotechnol. 1987, 38, 99-104. [CrossRef]

54. Kragović, M.; Pašalić, S.; Marković, M.; Petrović, M.; Nedeljković, B.; Momčilović, M.; Stojmenović, M. Natural and Modified Zeolite-Alginate Composites. Application for Removal of Heavy Metal Cations from Contaminated Water Solutions. Minerals 2018, 8, 11. [CrossRef]

55. Park, Y.; Ayoko, G.A.; Kurdi, R.; Horváth, E.; Kristóf, J.; Frost, R.L. Adsorption of phenolic compounds by organoclays: Implications for the removal of organic pollutants from aqueous media. J. Colloid Interface Sci. 2013, 406, 196-208. [CrossRef]

56. Potgieter, J.H.; Potgieter-Vermaak, S.S.; Kalibantonga, P.D. Heavy metals removal from solution by palygorskite clay. Miner. Eng. 2006, 19, 463-470. [CrossRef]

57. Rodeghero, E.; Chenet, T.; Martucci, A.; Ardit, M.; Sarti, E.; Pasti, L. Selective adsorption of toluene and n-hexane binary mixture from aqueous solution on zeolite ZSM-5: Evaluation of competitive behavior between aliphatic and aromatic compounds. Catal. Today 2019. [CrossRef] 
58. Stafiej, A.; Pyrzynska, K. Adsorption of heavy metal ions with carbon nanotubes. Sep. Purif. Technol. 2007, 58, 49-52. [CrossRef]

59. Bertolino, V.; Cavallaro, G.; Lazzara, G.; Milioto, S.; Parisi, F. Biopolymer-Targeted Adsorption onto Halloysite Nanotubes in Aqueous Media. Langmuir 2017, 33, 3317-3323. [CrossRef]

60. Cataldo, S.; Lazzara, G.; Massaro, M.; Muratore, N.; Pettignano, A.; Riela, S. Functionalized halloysite nanotubes for enhanced removal of lead(II) ions from aqueous solutions. Appl. Clay Sci. 2018, 156, 87-95. [CrossRef]

61. Cavallaro, G.; Lazzara, G.; Milioto, S.; Parisi, F.; Sanzillo, V. Modified Halloysite Nanotubes: Nanoarchitectures for Enhancing the Capture of Oils from Vapor and Liquid Phases. ACS Appl. Mater. Interfaces 2014, 6, 606-612. [CrossRef] [PubMed]

62. Ehsan, A.; Bhatti, H.N.; Iqbal, M.; Noreen, S. Native, acidic pre-treated and composite clay efficiency for the adsorption of dicationic dye in aqueous medium. Water Sci. Technol. 2016, 75, 753-764. [CrossRef] [PubMed]

63. Lvov, Y.; Aerov, A.; Fakhrullin, R. Clay nanotube encapsulation for functional biocomposites. Adv. Colloid Interface Sci. 2014, 207, 189-198. [CrossRef] [PubMed]

64. Mushtaq, M.; Bhatti, H.N.; Iqbal, M.; Noreen, S. Eriobotrya japonica seed biocomposite efficiency for copper adsorption: Isotherms, kinetics, thermodynamic and desorption studies. J. Environ. Manag. 2016, 176, 21-33. [CrossRef] [PubMed]

65. Zhao, Y.; Abdullayev, E.; Vasiliev, A.; Lvov, Y. Halloysite nanotubule clay for efficient water purification. J. Colloid Interface Sci. 2013, 406, 121-129. [CrossRef]

66. Santos, S.C.R.; Boaventura, R.A.R. Adsorption of cationic and anionic azo dyes on sepiolite clay: Equilibrium and kinetic studies in batch mode. J. Environ. Chem. Eng. 2016, 4, 1473-1483. [CrossRef]

67. Baskaralingam, P.; Pulikesi, M.; Elango, D.; Ramamurthi, V.; Sivanesan, S. Adsorption of acid dye onto organobentonite. J. Hazard. Mater. 2006, 128, 138-144. [CrossRef]

68. Bergaya, F.; Lagaly, G.; Vayer, M. Chapter 12.10 Cation and Anion Exchange. In Developments in Clay Science; Bergaya, F., Theng, B.K.G., Lagaly, G., Eds.; Elsevier: Amsterdam, The Netherlands, 2006; Volume 1, pp. 979-1001. ISBN 1572-4352.

69. Klika, Z.; Pustková, P.; Dudová, M.; Capkova, P.; Kliková, C.; Matys Grygar, T. The adsorption of methylene blue on montmorillonite from acid solutions. Clay Miner. 2011, 46, 461-471. [CrossRef]

70. Vopálka, D.; Gondolli, J.; Drtinová, B.; Klika, Z. Cesium uptake by Ca/Mg bentonite: Evaluation of sorption experiments by a multicomponent two-site ion-exchange model. J. Radioanal. Nucl. Chem. 2015, 304, 429-434. [CrossRef]

71. Calabrese, I.; Gelardi, G.; Merli, M.; Liveri, M.L.T.; Sciascia, L. Clay-biosurfactant materials as functional drug delivery systems: Slowing down effect in the in vitro release of cinnamic acid. Appl. Clay Sci. 2017, 135, 567-574. [CrossRef]

72. Sciascia, L.; Turco Liveri, M.L.; Merli, M. Kinetic and equilibrium studies for the adsorption of acid nucleic bases onto K10 montmorillonite. Appl. Clay Sci. 2011, 53, 657-668. [CrossRef]

73. Calabrese, I.; Cavallaro, G.; Scialabba, C.; Licciardi, M.; Merli, M.; Sciascia, L.; Liveri, M.L.T. Montmorillonite nanodevices for the colon metronidazole delivery. Int. J. Pharm. 2013, 457, 224-236. [CrossRef] [PubMed]

74. Calabrese, I.; Gelardi, G.; Merli, M.; Ritwo, G.; Sciascia, L.; Liveri, M.L.T. New tailor-made bio-organoclays for the remediation of olive mill waste water. IOP Conf. Ser. Mater. Sci. Eng. 2013, 47, 012040. [CrossRef]

75. Chaari, I.; Medhioub, M.; Jamoussi, F. Use of Clay to Remove Heavy Metals from Jebel Chakir Landfill Leachate. J. Appl. Sci. Environ. Sanit. 2011, 6, 143-148.

76. Sharma, P.; Borah, D.J.; Das, P.; Das, M.R. Cationic and anionic dye removal from aqueous solution using montmorillonite clay: Evaluation of adsorption parameters and mechanism. Desalin. Water Treat. 2016, 57, 8372-8388. [CrossRef]

77. Sciascia, L.; Casella, S.; Cavallaro, G.; Lazzara, G.; Milioto, S.; Princivalle, F.; Parisi, F. Olive mill wastewaters decontamination based on organo-nano-clay composites. Ceram. Int. 2019, 45, 2751-2759. [CrossRef]

78. Sarma, G.; Gupta, S.; Bhattacharyya, K. Adsorption of Crystal violet on raw and acid-treated montmorillonite, K10, in aqueous suspension. J. Environ. Manag. 2016, 171, 1-10. [CrossRef]

79. Mohanty, K.; Naidu, J.T.; Meikap, B.C.; Biswas, M.N. Removal of Crystal Violet from Wastewater by Activated Carbons Prepared from Rice Husk. Ind. Eng. Chem. Res. 2006, 45, 5165-5171. [CrossRef]

80. Au, W.; Pathak, S.; Collie, C.J.; Hsu, T.C. Cytogenetic toxicity of gentian violet and crystal violet on mammalian cells in vitro. Mutat. Res. Toxicol. 1978, 58, 269-276. [CrossRef] 
81. Rahimi, R.; Kerdari, H.; Rabbani, M. Adsorptive Removal of Crystal violet (CV), a Carcinogenic Textile Dye, from Aqueous Solution by Conducting Polyaniline/Hollow Manganese Ferrite Nanocomposites. In Proceedings of the ECSOC-14: The 14th International Electronic Conference on Synthetic Organic Chemistry, Basel, Switzerland, 1-30 November 2010.

82. Bumajdad, A.; Eastoe, J.; Mathew, A. Cerium oxide nanoparticles prepared in self-assembled systems. Adv. Colloid Interface Sci. 2009, 147-148, 56-66. [CrossRef]

83. Dubey, S.S.; Rao, B.S. Removal of cerium ions from aqueous solution by hydrous ferric oxide-A radiotracer study. J. Hazard. Mater. 2011, 186, 1028-1032. [CrossRef] [PubMed]

84. Hagen, A. Waste management-nuclear power, man and the environment. IAEA Bull. 2007, 24, 3-5.

85. Hung, I.M.; Wang, H.P.; Lai, W.H.; Fung, K.Z.; Hon, M.H. Preparation of mesoporous cerium oxide templated by tri-block copolymer for solid oxide fuel cell. Electrochim. Acta 2004, 50, 745-748. [CrossRef]

86. Ji, P.; Zhang, J.; Chen, F.; Anpo, M. Study of adsorption and degradation of acid orange 7 on the surface of $\mathrm{CeO}_{2}$ under visible light irradiation. Appl. Catal. B Environ. 2009, 85, 148-154. [CrossRef]

87. Park, J.-W.; Jeong, J.-H.; Yoon, W.-L.; Jung, H.; Lee, H.-T.; Lee, D.-K.; Park, Y.-K.; Rhee, Y.-W. Activity and characterization of the $\mathrm{Co}$-promoted $\mathrm{CuO}-\mathrm{CeO}_{2} / \gamma-\mathrm{Al}_{2} \mathrm{O}_{3}$ catalyst for the selective oxidation of $\mathrm{CO}$ in excess hydrogen. Appl. Catal. Gen. 2004, 274, 25-32. [CrossRef]

88. Yamashita, M.; Kameyama, K.; Yabe, S.; Yoshida, S.; Fujishiro, Y.; Kawai, T.; Sato, T. Synthesis and microstructure of calcia doped ceria as UV filters. J. Mater. Sci. 2002, 37, 683-687. [CrossRef]

89. Filipi, R.; Nesměrák, K.; Rucki, M.; Roth, Z.; Hanzlíková, I.; Tichý, M. Acute toxicity of rare earth elements and their compounds. Chem. Listy 2007, 101, 793-798.

90. Lin, W.; Huang, Y.-W.; Zhou, X.-D.; Ma, Y. Toxicity of Cerium Oxide Nanoparticles in Human Lung Cancer Cells. Int. J. Toxicol. 2006, 25, 451-457. [CrossRef]

91. Rogers, N.J.; Franklin, N.M.; Apte, S.C.; Batley, G.E.; Angel, B.M.; Lead, J.R.; Baalousha, M. Physico-chemical behaviour and algal toxicity of nanoparticulate $\mathrm{CeO}_{2}$ in freshwater. Environ. Chem. 2010, 7, 50-60. [CrossRef]

92. Röhder, L.A.; Brandt, T.; Sigg, L.; Behra, R. Influence of agglomeration of cerium oxide nanoparticles and speciation of cerium(III) on short term effects to the green algae Chlamydomonas reinhardtii. Aquat. Toxicol. 2014, 152, 121-130. [CrossRef]

93. Galle, P.; Berry, J.P.; Galle, C. Role of alveolar macrophages in precipitation of mineral elements inhaled as soluble aerosols. Environ. Health Perspect. 1992, 97, 145-147. [CrossRef] [PubMed]

94. Morgan, B.N.; Thomas, R.G.; McClellan, R.O. Influence of Chemical State of Cerium-144 on Its Metabolism Following Inhalation by Mice. Am. Ind. Hyg. Assoc. J. 1970, 31, 479-484. [CrossRef] [PubMed]

95. Sharma, A.; Talukder, G. Effects of metals on chromosomes of higher organisms. Environ. Mutagen. 1987, 9, 191-226. [CrossRef] [PubMed]

96. Kartha, C.C.; Eapen, J.T.; Radhakumary, C.; Kutty, V.R.; Ramani, K.; Lal, A.V. Pattern of cardiac fibrosis in rabbits periodically fed a magnesium-restricted diet and administered rare earth chloride through drinking water. Biol. Trace Elem. Res. 1998, 63, 19-30. [CrossRef]

97. Das, N.; Das, D. Recovery of rare earth metals through biosorption: An overview. J. Rare Earths 2013, 31, 933-943. [CrossRef]

98. Klika, Z.; Seidlerová, J.; Valášková, M.; Kliková, C.; Kolomazník, I. Uptake of Ce(III) and Ce(IV) on montmorillonite. Appl. Clay Sci. 2016, 132-133, 41-49. [CrossRef]

99. Erto, A.; Natale, F.; Musmarra, D.; Lancia, A. Modeling of single and competitive adsorption of cadmium and zinc onto activated carbon. Adsorption 2015, 21, 611-621. [CrossRef]

100. Hand, D.W.; Loper, S.; Ari, M.; Crittenden, J.C. Prediction of multicomponent adsorption equilibria using ideal adsorbed solution theory. Environ. Sci. Technol. 1985, 19, 1037-1043. [CrossRef]

101. Alekseeva, O.; Noskov, A.; Grishina, E.; Ramenskaya, L.; Kudryakova, N.; Ivanov, V.; Agafonov, A. Structural and Thermal Properties of Montmorillonite/Ionic Liquid Composites. Materials 2019, 12, 2578. [CrossRef]

102. Channei, D.; Phanichphant, S.; Nakaruk, A.; Mofarah, S.; Koshy, P.; Sorrell, C. Aqueous and Surface Chemistries of Photocatalytic Fe-Doped CeO2 Nanoparticles. Catalysts 2017, 7, 45. [CrossRef]

103. Nakada, R.; Takahashi, Y.; Tanimizu, M. Isotopic and speciation study on cerium during its solid-water distribution with implication for Ce stable isotope as a paleo-redox proxy. Geochim. Cosmochim. Acta 2013, 103, 49-62. [CrossRef] 
104. Nandi, B.K.; Goswami, A.; Das, A.K.; Mondal, B.; Purkait, M.K. Kinetic and Equilibrium Studies on the Adsorption of Crystal Violet Dye using Kaolin as an Adsorbent. Sep. Sci. Technol. 2008, 43, 1382-1403. [CrossRef]

105. Asif Tahir, M.; Bhatti, H.N.; Iqbal, M. Solar Red and Brittle Blue direct dyes adsorption onto Eucalyptus angophoroides bark: Equilibrium, kinetics and thermodynamic studies. J. Environ. Chem. Eng. 2016, 4, 2431-2439. [CrossRef]

106. Ullah, I.; Nadeem, R.; Iqbal, M.; Manzoor, Q. Biosorption of chromium onto native and immobilized sugarcane bagasse waste biomass. Ecol. Eng. 2013, 60, 99-107. [CrossRef]

107. Merli, M.; Sciascia, L.; Turco Liveri, M.L. Regression diagnostics applied in kinetic data processing: Outlier recognition and robust weighting procedures. Int. J. Chem. Kinet. 2010, 42, 587-607. [CrossRef]

108. Han, G.; Huang, Y.; Li, G.; Zhang, Y.; Jiang, T. Detailed Adsorption Studies of Active Humic Acid Fraction of a New Binder on Iron Ore Particles. Miner. Process. Extr. Metall. Rev. 2014, 35, 1-14. [CrossRef]

109. Ma, Y.; Lyu, L.; Guo, Y.; Fu, Y.; Shao, Q.; Wu, T.; Guo, S.; Sun, K.; Guo, X.; Wujcik, E.; et al. Porous lignin based poly(acrylic acid)/organo-montmorillonite nanocomposites: Swelling behaviors and rapid removal of $\mathrm{Pb}(\mathrm{II})$ ions. Polymer 2017, 128, 12-23. [CrossRef]

110. Sá, A.; Abreu, A.; Moura, I.; Vera Machado, A. Polymeric materials for metal sorption from hydric resources. In Water Purification; Academic Press, Elsevier: Cambridge, MA, USA, 2017; pp. $289-322$. ISBN 978-0-12-804300-4.

111. Sathishkumar, P.; Arulkumar, M.; Ashokkumar, V.; Mohd Yusoff, A.R.; Murugesan, K.; Palvannan, T.; Salam, Z.; Ani, F.N.; Hadibarata, T. Modified phyto-waste Terminalia catappa fruit shells: A reusable adsorbent for the removal of micropollutant diclofenac. RSC Adv. 2015, 5, 30950-30962. [CrossRef]

112. Sakin Omer, O.; Hussein, M.A.; Hussein, B.H.M.; Mgaidi, A. Adsorption thermodynamics of cationic dyes (methylene blue and crystal violet) to a natural clay mineral from aqueous solution between 293.15 and 323.15 K. Arab. J. Chem. 2018, 11, 615-623. [CrossRef]

113. Alhendawi, H.M.H.; Brunet, E.; Payán, E.R.; Juanes, O.; Ubis, J.C.R.; Al-Asqalany, M. Surfactant-assisted intercalation of crystal violet in layered $\gamma$-zirconium phosphate. Dye uptake from aqueous solutions. J. Incl. Phenom. Macrocycl. Chem. 2012, 73, 387-396. [CrossRef]

114. Yang, H.; Zhou, D.; Chang, Z.; Zhang, L. Adsorption of crystal violet onto amino silica: Optimization, equilibrium, and kinetic studies. Desalin. Water Treat. 2014, 52, 6113-6121. [CrossRef]

115. Lee, Y.-R.; Yu, K.; Ravi, S.; Ahn, W.-S. Selective Adsorption of Rare Earth Elements over Functionalized Cr-MIL-101. ACS Appl. Mater. Interfaces 2018, 10, 23918-23927. [CrossRef]

116. Xu, S.; Wang, Z.; Gao, Y.; Zhang, S.; Wu, K. Adsorption of Rare Earths (III) Using an Efficient Sodium Alginate Hydrogel Cross-Linked with Poly- $\gamma$-Glutamate. PLoS ONE 2015, 10, e0124826. [CrossRef]

117. Zhu, Y.; Zheng, Y.; Wang, A. Preparation of granular hydrogel composite by the redox couple for efficient and fast adsorption of La(III) and Ce(III). J. Environ. Chem. Eng. 2015, 3, 1416-1425. [CrossRef]

118. Afroze, S.; Sen, T.K. A Review on Heavy Metal Ions and Dye Adsorption from Water by Agricultural Solid Waste Adsorbents. Water Air Soil Pollut. 2018, 229, 225. [CrossRef]

119. Chougui, A.; Zaiter, K.; Belouatek, A.; Asli, B. Heavy metals and color retention by a synthesized inorganic membrane. Arab. J. Chem. 2014, 7, 817-822. [CrossRef]

120. Zeng, J.; He, Q.; Zhou, H.; Sun, X.; Zhang, J. Recovery of cerium(III) from aqueous solutions by complexation-ultrafiltration process. Asia Pac. J. Chem. Eng. 2012, 7, 940-947. [CrossRef]

121. Grégorio, C.; Lichtfouse, É. Advantages and disadvantages of techniques used for wastewater treatment. Environ. Chem. Lett. 2019, 17, 145-155.

122. Dawodu, F.; Akpomie, K.; Abuh, M. Equilibrium Isotherm Studies on the Batch Sorption of Copper(II) ions from Aqueous Solution unto Nsu Clay. Int. J. Sci. Eng. Res. 2012, 3, 1-7.

123. Malik, U.R.; Hasany, S.M.; Subhani, M.S. Sorptive potential of sunflower stem for Cr(III) ions from aqueous solutions and its kinetic and thermodynamic profile. Talanta 2005, 66, 166-173. [CrossRef]

124. Singh, T.S.; Pant, K.K. Equilibrium, kinetics and thermodynamic studies for adsorption of As(III) on activated alumina. Sep. Purif. Technol. 2004, 36, 139-147. [CrossRef]

125. Uddin, M.K. A review on the adsorption of heavy metals by clay minerals, with special focus on the past decade. Chem. Eng. J. 2017, 308, 438-462. [CrossRef] 
126. Bertolino, V.; Cavallaro, G.; Lazzara, G.; Merli, M.; Milioto, S.; Parisi, F.; Sciascia, L. Effect of the Biopolymer Charge and the Nanoclay Morphology on Nanocomposite Materials. Ind. Eng. Chem. Res. 2016, 55, 7373-7380. [CrossRef]

127. Bromberg, L.; Straut, C.M.; Centrone, A.; Wilusz, E.; Hatton, T.A. Montmorillonite Functionalized with Pralidoxime As a Material for Chemical Protection against Organophosphorous Compounds. ACS Appl. Mater. Interfaces 2011, 3, 1479-1484. [CrossRef]

128. Calabrese, I.; Cavallaro, G.; Lazzara, G.; Merli, M.; Sciascia, L.; Liveri, M.L.T. Preparation and characterization of bio-organoclays using nonionic surfactant. Adsorption 2016, 22, 105-116. [CrossRef]

129. Cui, L.; Tarte, N.H.; Woo, S.I. Effects of Modified Clay on the Morphology and Properties of PMMA/Clay Nanocomposites Synthesized by in Situ Polymerization. Macromolecules 2008, 41, 4268-4274. [CrossRef]

130. Mauro, N.; Chiellini, F.; Bartoli, C.; Gazzarri, M.; Laus, M.; Antonioli, D.; Griffiths, P.; Manfredi, A.; Ranucci, E.; Ferruti, P. RGD-mimic polyamidoamine-montmorillonite composites with tunable stiffness as scaffolds for bone tissue-engineering applications. J. Tissue Eng. Regen. Med. 2017, 11, 2164-2175. [CrossRef]

131. Fang, Z.; Liu, B.; Luo, J.; Ren, Y.; Zhang, Z. Efficient conversion of carbohydrates into 5-hydroxymethylfurfural catalyzed by the chromium-exchanged montmorillonite K-10 clay. Biomass Bioenergy 2014, 60, 171-177. [CrossRef]

(C) 2019 by the authors. Licensee MDPI, Basel, Switzerland. This article is an open access article distributed under the terms and conditions of the Creative Commons Attribution (CC BY) license (http://creativecommons.org/licenses/by/4.0/). 